\title{
KEDUDUKAN PENGEMBANGAN BAHAN AJAR DALAM TEKNOLOGI PEMBELAJARAN
}

\author{
Oleh: Andi Haris, M.Pd \\ Dosen Teknologi Pendidikan FKIP Universitas Samawa
}

\begin{abstract}
ABSTRAK
Teknologi pembelajaran adalah penerapan secara sistematis dan sistematis strategi-strategi dan teknik-teknik yang diambil dari konsep-konsep ilmu perilaku dan limu-ilmu bersifat fisik serta pengetahuan lain untuk keperluan pemecahan masalah-masalah pembelajaran. Pengembangan bahan ajar sangatlah diperlukan dalam proses pembelajaran peserta didik dengan tujuan sebagai membantu peserta dalam mempelajari sesuatu, menyediakan berbagai jenis pilihan bahan ajar, sehingga mencegah timbulnya rasa bosan pada peserta didik, memudahkan peserta didik dalam melaksanakan pembelajaran, dan agar kegiatan pembelajaran menjadi lebih menarik.
\end{abstract}

\section{Kata kunci: Kedudukan Bahan Ajar, Teknologi Pembelajaran}

\section{PENDAHULUAN}

Perkembangan pendidikan dan pembelajaran pada era globalisasi yang dilengkapi dengan teknologi informasi dan komunikasi, menuntut diri kita sebagai pendidik maupun non pendidik menggagas model pembelajaran yang menyenangkan. Model pembelajaran yang menyenangkan ini, tentunya menuntut pendidik memiliki kreativitas dalam menghasilkan produk tersebut, salah satunya bahan ajar. Pengembangan bahan ajar sekarang pada kalangan pendidik tampaknya masih kurang berkembang, karena kekurangan referensi yang relevan, jurnal, bahkan hasil penelitian yang sulit untuk diperoleh oleh kalangan pendidik.

Kekurangan-kekurangan inilah yang pada umumnya, pendidik hanya menyediakan bahan ajar yang menoton, pokoknya yang sudah tersedia dan tinggal pakai serta tidak perlu harus 
Artikel Teknologi Pendidikan 2012

bersusah payah membuatnya yang memakan waktu dan tenaga yang tidak sedikit. Bahkan harus mengorbankan waktu santai untuk duduk di depan layar computer, untuk menghasilkan bahan ajar yang berkualitas. Sehingga pada akhirnya, yang harus menjadi korban adalah peserta didik. Peserta didik akan mengalami kebosanan mengikuti proses pembelajaran yang berdampak pada tidak efektif dan efesiennya pembelajaran itu sendiri.

Persoalan di atas, tentunya menjadi persoalan serius, persoalan yang tidak sekedar bisa dipecahkan dalam tataran wacana semata, namun harus ada aksi nyata guna mengatasi persoalan tersebut. Salah satunya, para pendidik perlu membangun kreativitas mereka sendiri agar mampu membuat bahan ajar yang inovatif. Muslim dalam Gafar (2002: 23) mengemukakan bahwa bahan ajar yang bermakna mampu menghubungkan kegiatan belajar sekarang dengan pengalaman sebelumnya dan kegiatan belajar yang akan datang, dengan ditandai mudahnya dipahami informasi yang disajikan. Demikian pula pendapat Panen (1994) bahwa bahan belajar hendaknya berorientasi pada belajar peserta didik secara individual.

\section{PEMBAHASAN}

\section{Kedudukan Pengembangan dalam teknologi pembelajaran}

Definisi teknologi pembelajaran yang dikemukakan oleh Seels \& Richey (1994:10), adalah teori dan praktek dalam desain, pengembangan, pemanfaatan, pengelolaan dan penilaian proses dan sumber belajar. Tujuan teknologi pembelajaran adalah untuk memacu (merangsang) dan memicu (menumbuhkan) belajar. Ungkapan ini, dipilih untuk memberi tekanan pada hasil belajar dan menjelaskan bahwa belajar adalah tujuannya dan pembelajaran adalah sarana untuk mencapai tujuan tersebut.

Pendapat lain mengatakan bahwa teknologi pembelajaran adalah penerapan secara sistematis dan sistematis strategi-strategi dan teknik-teknik yang diambil dari konsep-konsep ilmu perilaku dan limu-ilmu bersifat fisik serta pengetahuan lain untuk keperluan pemecahan masalahmasalah pembelajaran (Uno. H. B., Lamatenggo. N., \& Koni. S, 2010: 93). Sedangkan definisi AECT (dalam Januszewski. A. \& Molenda. M. 2008: 1); Pribadi. B. A (2009: 65) bahwa teknologi pembelajaran adalah sebuah studi dan praktek yang berlandaskan etika dalam memfasilitasi belajar dan meningkatkan kinerja melalui penciptaan, penggunaan, pengelolaan pelbagai proses dan sumber teknologi yang tepat. 
Artikel Teknologi Pendidikan 2012

Belajar yang dapat terlihat dengan adanya perubahan pada pengetahuan, keterampilan atau sikap, merupakan kriteria atau ukuran pembelajaran. Dalam definisi disebutkan belajar menyangkut adanya perubahan yang relatif permanen pada pengetahuan atau perilaku seseorang karena pengalaman (Mayer, 1982:1040). Berlo (1960) menunjukkan bahwa unsur-unsur pada proses belajar dengan proses komunikasi sejalan. Pada komunikasi, pesan diolah dan disalurkan kembali sebagai umpan balik kepada pengirim pesan. Sedangkan pada proses belajar, orang menanggapi, menafsirkan, dan merespon terhadap rangsangan, dan mengambil pelajaran dari akibat tanggapan tersebut.

Menurut Degeng (1986) bahwa belajar adalah pengaitan pengetahuan baru pada struktur kognitif yang sudah dimiliki sibelajar. Pengaitan-pengaitan ini akan membentuk suatu struktur kognitif baru yang lebih mantap, yang dapat dipandang sebagai hasil belajar. Konsepsi-konsepsi ini akan menjadi pijakan dalam identifikasi dan pengembangan strategi pembelajaran. Sedangkan Robert Heinich dkk (2005) belajar diartikan sebagai “......development of new knowledge, skills, or attitudes as individual interact with learning resources" (belajar merupakan sebuah proses pengembangan pengetahuan, keterampilan, dan sikap yang terjadi manakala seseorang melakukan interaksi secara intensif dengan sumber-sumber belajar.

Dewasa ini telah banyak usaha yang dilakukan untuk memudahkan proses-proses internal yang berlangsung ketika seseorang belajar. Semuanya diacukan agar proses belajar menjadi lebih efektif dan efesien. Bila diungkapkan dari sisi konsepsi pembelajaran, usaha-usaha ini dilakukan untuk meningkatkan kualitas variabel-variabel eksternal (pembelajaran) agar pengaruhnya pada proses-proses internal menjadi lebih efektif. Usaha-usaha ini dijalankan dibawah suatu disiplin ilmu yang oleh Glaser (1976) disebut "ilmu merancang” pembelajaran, atau menurut Degeng (1986) disebut "ilmu pembelajaran".

Tujuan utama teknologi pembalajaran adalah mengidentifikasi dan memecahkan masalah belajar. Di samping itu, membantu meningkatkan efesiensi pada proses pembelajaran. Efesiensi tersebut tampak pada (1) peningkatan kualitas belajar atau tingkat penguasaan peserta didik, (2) penghematan waktu yang digunakan untuk belajar guna mencapai tujuan, (3) peningkatan daya tampung tanpa mengurangi kualitas belajar, dan (4) penurunan biaya tanpa mengurangi kualitas belajar peserta didik (Percipal dan Ellington, 1988). Agar dapat tercapai maksud tersebut, teknologi pembelajaran melakukan upaya dengan cara pemanfaatan sumber belajar dan pengembangan dengan kriteria (1) interaksi belajar yang mengacu pada aktivitas belajar, dan (2) 
Artikel Teknologi Pendidikan 2012

situasi belajar yang sesuai dengan kemampuan peserta didik (Miarso, 1987). Menurut AECT (1994: 6) mengklasifikasi sumber belajar menjadi enam (1) pesan, (2) orang, (3) material atau bahan, (4) alat atau peralatan, (5) teknik, dan (6) lingkungan atau latar.

Pengembangan adalah proses penterjemahan spesifikasi desain ke dalam bentuk fisik (Seels \& Richey, 1994: 38). Kawasan pengembangan mencakup banyak variasi teknologi yang digunakan dalam pembelajaran. Walaupun demikian, tidak berarti lepas dari teori dan praktek yang berhubungan dengan belajar dan desain. Tidak pula kawasan tersebut berfungsi bebas dari penilaian, pengelolaan atau pemanfaatan. Melainkan timbul karena dorongan teori dan desain dan harus tanggap terhadap tuntutan penilaian formatif dan praktek pemanfaatan serta kebutuhan pengelolaan. Begitu pula kawasan pengembangan, tidak hanya terdiri dari perangkat keras pembelajaran, melainkan juga mencakup perangkat lunaknya, bahan-bahan visual dan audio, serta program atau paket yang merupakan paduan berbagai paduan.

Di dalam kawasan pengembangan terdapat keterkaitan yang kompleks antara teknologi dan teori yang mendorong baik desain pesan maupun strategi pembelajaran. Pada dasarnya kawasan pengembangan dapat dijelaskan dengan adanya: (a) pesan yang didorong oleh isi, (b) strategi pembelajaran yang didorong oleh teori, dan (c) manifestasi fisik dari teknologi, perangkat keras, perangkat lunak, dan bahan pembelajaran (Seels \& Richey, 1994: 39). Kawasan pengembangan dapat diorganisasikan dalam empat kategori (a) teknologi cetak (yang menyediakan landasan untuk kategori yang lain), (b) teknologi audiovisual, (c) teknologi berasaskan komputer, dan (d) teknologi terpadu.

Jenis bahan ajar ada empat, yakni: (1) bahan ajar pandang (visual) terdiri atas bahan cetak (printed) seperti, hand out, buku, modul, lembar kerja siswa, brosur, leaflet, wallchart, foto/gambar, dan non cetak (non printed) seperti model/maket; (2) bahan ajar dengar (audio) seperti kaset, radio, piringan hitam, dan kompact disk audio; (3) bahan ajar pandang dengar (audio visual) seperti video compact disk, film; (4) bahan ajar multimedia interaktif (interactive teaching material) seperti CAI (Computer Assisted Instruction), compact disk (CD) multimedia pembelajaran interaktif, dan bahan ajar berbasis web (web based learning materials) (Amri. S. \& Ahmadi. L. K. 2010: 161). 
Artikel Teknologi Pendidikan 2012

\section{Definisi Bahan Ajar}

Bahan ajar didefinisikan "sebagai bahan pembelajaran yang berupa barang-barang (media atau perangkat lunak 'software' yang berisi pesan untuk disampaikan dengan menggunakan peralatan" (AECT, 1986: 10). Bahan ajar ini dapat dilihat dari dua sudut, yakni sebagai proses dan sebagai produk. Sebagai proses, bahan ajar berfungsi sebagai alat penunjang proses pembelajaran dalam rangka penyampaian bahan pembelajaran kepada pebelajar. Sebagai produk, bahan ajar merupakan hasil dari serangkaian bahan yang dimuat dalam bentuk buku sesuai kurikulum yang berlaku dan sebagai sumber belajar. Sedangkan menurut Amri. S. \& Ahmadi. L.K (2010: 159) mengatakan bahwa bahan ajar adalah segala bentuk bahan (bahan tertulis maupun tidak tertulis) yang digunakan untuk membantu guru/instruktur dalam melaksanakan kegiatan belajar mengajar di kelas.

Menurut Bacon (dalam Hakim, 2001: 18) bahan ajar adalah buku yang dirancang untuk bahan perkuliahan di kelas. Buku ajar tersebut disusun secara umum dan disiapkan oleh ahli bidang studi tertentu dan dilengkapi dengan saran-saran pembelajaran yang sesuai. Sedangkan Buckingham (dalam Tarigan, 1989: 11) menegaskan bahwa buku ajar adalah sarana belajar umum yang digunakan di sekolah dan diperguruan tinggi.

National Centre for Competency Based Training (2007) bahan ajar adalah segala bentuk bahan yang digunakan untuk membantu guru atau instruktur dalam melaksanakan proses pembelajaran di kelas. Bahan ajar adalah seperangkat materi yang disusun secara sistematis, baik tertulis maupun tidak tertulis, sehingga terciptanya lingkungan atau suasana yang memungkinkan peserta didik untuk belajar (Degeng, 2008). Bahan ajar adalah informasi, alat, dan teks yang diperlukan guru atau instruktur untuk perencanaan dan penelaahan implementasi pembelajaran (Andi Prastowo, 2012).

Terkait dengan bahan ajar, buku teks yang sering digunakan untuk keperluan pembelajaran memiliki perbedaan makna seperti yang dijelaskan oleh Lewis dan Paine (dalam Hakim, 2001: 19). Perbedaan makna tersebut akan terlihat pada tabel 1.1 sebagai berikut: 


\section{Tabel 1.1 Perbedaan Buku Teks dengan Bahan Ajar}

\begin{tabular}{|c|c|}
\hline \multicolumn{2}{|c|}{ Perbedaan } \\
\hline Buku Teks & Bahan Ajar Yang Dikembangkan \\
\hline $\begin{array}{l}\text { Perbedaan makna dalam buku teks yaitu: } \\
\text { a. Mengasumsi minat pembaca, } \\
\text { b. Ditulis terutama untuk digunakan oleh } \\
\text { pembelajar, } \\
\text { c. Dirancang untuk dipasarkan secara } \\
\text { luas, } \\
\text { d. Tidak menjelaskan tujuan } \\
\text { pembelajaran, } \\
\text { e. Disusun secara linier, } \\
\text { f. Strukturnya berdasarkan logika bidang } \\
\text { ilmu, } \\
\text { g. Tidak memberikan latihan, } \\
\text { h. Tidak mengantisipasi kesukaran } \\
\text { belajar pebelajar, } \\
\text { i. Tidak memberikan rangkuman, } \\
\text { j. Gaya penulisan (bahasanya) naratif } \\
\text { tetapi tidak komunikatif, } \\
\text { k. Sangat padat, } \\
\text { 1. Tidak mempunyai mekanisme untuk } \\
\text { mengumpulkan umpan balik dari } \\
\text { pembaca, dan } \\
\text { m. Tidak memberikan saran-saran cara } \\
\text { mempelajari buku tersebut. }\end{array}$ & $\begin{array}{l}\text { Dalam buku bahan ajar terdapat makna yaitu: } \\
\text { a. Menimbulkan minat pembaca, } \\
\text { b. Ditulis dan dirancang untuk digunakan oleh } \\
\text { pebelajar, } \\
\text { c. Menjelaskan tujuan pembelajaran, } \\
\text { d. Disusun berdasarkan pola belajar yang } \\
\text { fleksibel, } \\
\text { e. Strukturnya berdasarkan kebutuhan pebelajar } \\
\text { dan kompetensi akhir yang akan dicapai, } \\
\text { f. Berfokus pada pemberian kesempatan bagi } \\
\text { pebelajar yang berlatih, } \\
\text { g. Mengakomodasi kesukaran belajar pebelajar, } \\
\text { h. Selalu memberikan rangkuman, } \\
\text { i. Gaya penulisan (bahasanya) komunikatif dan } \\
\text { semi formal, } \\
\text { j. Kepadatan materi berdasarkan kebutuhan } \\
\text { pebelajar, } \\
\text { k. Dikemas untuk digunakan dalam proses } \\
\text { pembelajaran } \\
\text { 1. Mempunyai mekanisme untuk mengumpulkan } \\
\text { umpan balik dari pebelajar, dan } \\
\text { m. Memjelaskan cara mempelajari buku bahan } \\
\text { ajar. }\end{array}$ \\
\hline
\end{tabular}

Selanjutnya menurut Buckingham (dalam Tarigan, 1989: 16) menyimpulkan keunggulan yang diperoleh dari pemanfaatan bahan ajar yaitu antara lain: (1) memiliki kesempatan mempelajari sesuai dengan kecepatan masing-masing, (2) kesempatan mengulangi atau meninjau kembali, (3) kemungkinan mengadakan pemeriksaan atau pengecekan terhadap ingatan, (4) kemudahan membuat catatan pada pemakaian selanjutnya, (5) kesempatan khusus yang dapat ditampilkan oleh adanya sarana-sarana visual yang menunjang belajar.

Di samping keunggulan yang diperoleh dari pemanfaatan bahan ajar dalam pembelajaran, menurut Syahid (2003: 22) terdapat pula keterbatasan dalam pemanfaatannya, antara lain: (1) terbatas pada kelas atau pada pebelajar yang menggunakannya, (2) menimbulkan sikap malas dari pebelajar untuk mencari dan mempelajari selain bahan ajar, dan (3) akibat perkembangan dan perubahan yang terjadi dalam bidang teknologi dan informasi, kemungkinan isi bahan ajar tertinggal. 
Artikel Teknologi Pendidikan 2012

Adapun ciri-ciri bahan ajar yang berkualitas menurut Greene \& Petty (dalam Hakim, 2001: 22), adalah (a) menarik perhatian, (b) membangkitkan motivasi belajar, (c) memuat ilustrasi yang menarik, (d) penggunaan bahasa yang jelas, (e) adanya keterkaitan pelajaran yang lain, dan (f) terhindar dari konsep-konsep yang samar. Sedangkan fungsi bahan ajar dilihat dari karakteristiknya dalam kegiatan pembelajaran adalah (a) memberikan petunjuk yang jelas bagi pembelajar dan pengelola pembelajaran, (b) menyediakan bahan alat yang lengkap dan diperlukan untuk setiap kegiatan pembelajaran, (c) merupakan media penghubung antara pembelajar dan pebelajar, (d) dapat dipakai oleh pebelajar sendiri dalam mencapai kemampuan yang telah ditetapkan, dan (e) dapat dipakai sebagai program perbaikan (Joni, dkk, 1984: 4).

Kita seorang pendidik dituntut untuk dapat memeiliki keterampilan lebih (plus-plus) yang kreatif mendesain suatu bahan ajar yang memungkinkan peserta didik dapat secara langsung memanfaatkan sumber belajar yang tersedia. Pentingnya pembuatan bahan ajar, maka ada 2 klasifikasi utama fungsi bahan ajar adalah (1) Fungsi bahan ajar menurut pihak yang memanfaatkan bahan ajar, (2) Fungsi bahan ajar menurut strategi pembelajaran yang digunakan (Andi Prastowo, 2012: 24).

Lebih lanjut dijelaskan Andi Prastowo (2012: 25) bahwa fungsi bahan ajar menurut pihak yang memanfaatkan bahan ajar dapat dibagi menjadi dua bagian yaitu bagi pendidik dan bagi peserta didik. Untuk pendidik fungsi bahan ajar adalah (a) menghemat waktu pendidik dalam mengajar, (b) mengubah peran pendidik dari seorang pengajar menjadi seorang fasilitator, (c) meningkatkan proses pembelajaran menjadi lebih efektif dan interaktif, (d) sebagai pedoman bagi pendidik yang akan mengarahkan semua aktivitasnya dalam proses pembelajaran dan merupakan substansi kompetensi yang semestinya diajarkan kepada peserta didik, dan (e) sebagai alat evaluasi pencapaian atau penguasaan hasil pembelajaran. Sedangkan fungsi bahan ajar bagi peserta didik adalah (a) peserta didik dapat belajar tanpa harus ada pendidik atau teman peserta didik yang lain, (b) peserta didik dapat belajar kapan saja dan dimana saja ia kehendaki, (c) peserta didik dapat belajar sesuai kecapatannya masing-masing, (d) peserta didik dapat belajar menurut urutan yang dipilihnya sendiri, (e) membantu potensi peserta didik untuk menjadi pelajar/mahasiswa yang mandiri, dan (f) sebagai pedoman bagi peserta didik yang akan mengarahkan semua aktivitasnya dalam proses pembelajaran dan merupakan substansi kompetensi yang seharusnya dipelajari atau dikuasainya. 
Artikel Teknologi Pendidikan 2012

Kemudian Fungsi bahan ajar menurut strategi pembelajaran yang digunakan oleh Andi Prastowo (2012: 26) adalah (1) sebagai pembelajaran klasikal, mencakup; (a) sebagai satu-satunya sumbeli proses informasi serta pengawas dan pengendali proses pembelajaran (b) sebagai bahan pendukung proses pembelajaran yang diselenggarakan. (2) sebagai pembelajaran individual, mencakup; (a) sebagai media utama dalam proses pembelajaran, (b) sebagai alat yang digunakan untuk Menyusun dan mengawasi proses peserta didik dalam memperoleh informasi, (c) sebagai penunjang media pembelajaran individual lainnya. dan (3) sebagai pembelajaran kelompok, mencakup; (a) sebagai bahan yang terintegrasi dengan proses belajar kelompok, dengan cara memberikan informasi tentang latar belakang materi, informasi tentang orang-orang yang terlibat dalam belajar kelompok, serta petunjuk tentang proses pembelajaran kelompoknya sendiri, (b) sebagai bahan pendukung bahan belajar utama, dan apabila dirancang sedemikian rupa, maka dapat meningkatkan motivasi belajar peserta didik.

Kemudia menurut Diknas (2004: 26) tujuan pembuatan bahan ajar adalah (a) membantu peserta didik dalam mempelajari sesuatu, (b) menyediakan berbagai jenis pilihan bahan ajar, sehingga mencegah timbulnya rasa bosan pada peserta didik, (c) memudahkan peserta didik dalam melaksanakan pembelajaran, dan (d) agar kegiatan pembelajaran menjadi lebih menarik.

Kemudian manfaat bahan ajar menurut Diknas (2004: 28) dapat dibagi menjadi dua bagian yaitu (1) kegunaan bagi pendidik yang mencakup; (a) pendidik akan memiliki bahan ajar yang dapat membantu dalam pelaksanaan kegiatan pembelajaran, (b) bahan ajar dapat diajukan sebagai karya yang dinilai untuk menambah angka kredit pendidik guna keperluan kenaikan pangkat, dan (c) menambah penghasilan pendidik jika hasil karnyanya diterbitkan. (2) bagi peserta didik, mencakup; (a) kegiatan pembelajaran menjadi lebih menarik, (b) peserta didik lebih banyak mendapatkan kesempatan untuk belajar secara mandiri dengan bimbingan pendidik, dan (b) peserta didik mendapatkan kemudahan dalam mempelajari setiap kompetensi yang harus dikuasainya.

\section{Pengembangan Bahan Ajar}

Tujuan utama teknologi pembelajaran adalah mengidentifikasi dan memecahkan masalahmasalah belajar yang berkaitan dengan masalah belajar manusia (Astina, 1997: 16). Kenyataan di lapangan menunjukkan bahwa sumber-sumber belajar pada umumnya tidak dikembangkan sesuai 
Artikel Teknologi Pendidikan 2012

dengan Learner's need (kebutuhan peserta didik), sehingga tujuan tersebut sering tidak menjadi kenyataan.

Sebelum pengembangan bahan ajar diwujudkan ada dua hal yang perlu ditetapkan, Pertama; penetapan strategi pengorganisasian isi, dan kedua; penggunaan media untuk menyampaikan isi pembelajaran (Atrup, 1992). Dengan demikian pengembangan bahan ajar adalah suatu proses yang sistematis dengan mengidentifikasi, mengembangkan, mengevaluasi isi, serta strategi pembelajaran yang diarahkan untuk mencapai tujuan pembelajaran yang efektif dan efesien.

Pengembangan bahan ajar menurut Banathy (1991) adalah suatu proses yang sistematis dalam mengidentifikasi, mengembangkan, dan mengevaluasi isi dan strategi pembelajaran yang diarahkan untuk mencapai tujuan pembelajaran yang efektif dan efesien. Untuk itu, pengembangan bahan ajar hendaknya memiliki kriteria (1) dapat membantu kegiatan pembelajaran secara individu, (2) dapat merespon secara maksimal, (3) memuat pesan secara potensial, (4) mampu memberikan kesempatan belajar yang diminati, dan (5) memberikan saran dan petunjuk serta informasi balikan tentang tingkat kemajuan yang dicapai peserta didik.

Menurut Degeng (1986: 18) dan Uno. B., dkk (2010: 37-38), dikatakan bahwa: (1) Keefektifan pembelajaran biasanya diukur dengan tingkat pencapaian sibelajar. Ada empat aspek penting yang dapat dipakai untuk mempreskripsikan keefektifan pembelajaran, yaitu (a) kecermatan penguasaan prilaku yang dipelajari atau juga sering disebut dengan "tingkat kesalahan", (b) kecepatan unjuk kerja, (c) tingkat alih belajar, dan (d) tingkat retensi dari apa yang dipelajari. (2) Efesiensi pembelajaran, biasanya diukur dengan rasio antara keefektifan dan jumlah waktu yang dipakai sibelajar dan/atau jumlah biaya pembelajaran yang digunakan. (3) Daya tarik pembelajaran, biasanya diukur dengan mengamati kecenderungan peserta didik untuk tetap/terus belajar. Daya tarik pembelajaran erat sekali kaitannya dengan daya tarik bidang studi, dimana kualitas pembelajaran biasanya akan mempengaruhi keduanya. Itulah sebabnya, pengukuran kecenderungan peserta didik untuk terus atau tidak terus belajar dapat dikaitkan dengan proses pembelajaran itu sendiri atau dengan bidang studi.

Pengembangan bahan ajar sekiranya ditulis dengan menggunakan strategi pembelajaran yang sama seperti yang digunakan dalam kelas biasa. Menulis bahan ajar berarti mengajarkan isi suatu matakuliah melalui tulisan. Oleh karena itu, bahasa yang digunakan bukan bahasa buku teks yang bersifat sangat resmi atau sangat formal dan setengah lisan (Degeng, 1989b: 143). Lebih 
Artikel Teknologi Pendidikan 2012

lanjut dijelaskan ketika menulis bahan ajar, pengembang hendaknya membayangkan bahwa ia sedang memberi kuliah tatap muka kepada seseorang pembaca, seolah-olah sedang mengajak pembaca berbicara. Dengan demikian, pengembang diharapkan menggunakan bahasa yang berada diantara bahasa formal dan bahasa tidak formal (lisan).

Susunan tulisan dalam suatu bahan ajar mencerminkan strategi pembelajaran atau urutan kegiatan-kegiatan pembelajaran yang biasa digunakan oleh pembelajar dalam perkuliahan tatap muka. Menurut Degeng (1989b; 2008: 1-2) bahan ajar sebaiknya dikembangkan mengikuti ketentuan-ketentuan umum serta ketentuan-ketentuan khusus untuk setiap bab. Setiap bab sebaiknya diseragamkan memasukkan komponen-komponen sebagai berikut:

1. Bagian pendahuluan

Bagian pendahuluan terdiri dari kerangka isi, tujuan pembelajaran, deskripsi singkat, dan relevansi serta kata-kata kunci. (a) Kerangka isi, yang diletakkan pada setiap awal bab, berfungsi untuk memperlihatkan kaitan antara bab yang sedang dibahas dengan bab sebelumnya serta bab sesudahnya. Untuk memusatkan perhatian peserta didik, bab yang sedang dibahas diberi tanda yang berbeda (umpamanya, kotak yang berbayang). (b) Tujuan. Mengungkapkan kemampuan apa yang harus dimiliki oleh peserta didik setelah selesai mengikuti kegiatan belajar bab tersebut. Tujuan hendaknya diungkapkan agak operasional sehingga pencapaiannya mudah diukur. (c) Deskripsi singkat tentang isi bab (diungkapkan dalam satu paragraf), dengan membaca deskripsi tersebut peserta didik akan mendapatkan gambaran umum tentang keseluruhan isi dan bab yang dibahas. (d) Relevansi isi bab (diungkapkan dalam satu paragraf), yang mana kaitan antara isi bab yang sedang dipelajari dengan isi bab yang telah dipelajari sebelumnya, dan kegunaannya dalam mempelajari bab berikutnya, serta kegunaannya dalam keseluruhan proses belajar. (e) Kata-kata kunci. Kata-kata kunci perlu diidentifikasi dan dikemukakan dalam bagian ini.

2. Bagian isi

Bagian isi adalah "inti" suatu bab yang terdiri dari beberapa bab bagian dan sub bab bagian sebagai berikut: (a) Judul, (b) Uraian atau penjelasan (explanation) secara terperinci tentang isi bab, yang diikuti oleh contoh-contoh konkrit (examples) dan non-contoh, serta gambar atau grafik. Uraian dapat dimulai dengan contoh-contoh, atau kasus-kasus, kemudian baru diikuti dengan penjelasan tentang konsep yang dimaksud. (c) Ringkasan dari konsep atau prinsip yang telah dipelajari dalam bab berikut. (d) Latihan (exercise) yang berisi kegiatan yang 
Artikel Teknologi Pendidikan 2012

harus dilakukan peserta didik setelah membaca uaraian di atas. Latihan ini berisi perintah yang dilakukan peserta didik dengan mengikuti petunjuk-petunjuk secara bertahap, langkah demi langkah. Tujuan latihan ini adalah agar peserta didik benar-benar menguasai konsep yang telah dibahas.

Menurut Amri. S. \& Ahmadi. L. K (2010: 161) bahwa penyusunan bahan ajar disesuaikan dengan kurikulum dasarnya, yakni (a) analisis KD (Kurikulum Dasar) - indikator, (b) analisis sumber belajar, dan (c) pemilihan dan penentuan bahan ajar. Lebi lanjut dijelaskan dalam penyusunan bahan ajar cetak harus melihat dulu rancangan pendidikannya, jika sudah sesuai, maka disesuaikan dengan: (1) susunan tampilan, (2) bahasa yang mudah, (3) menguji pemahaman, (4) stimulan, (5) kemudahan dibaca, dan (6) materi instruksional.

Menurut Widodo. C. S \& Jasmani (2008: 42), bahan ajar harus dikembangkan sesuai dengan kaidah-kaidah pengembangan bahan ajar, yakni (1) bahan ajar harus disesuaikan dengan peserta didik yang sedang mengikuti proses belajar mengajar, (2) bahan ajar diharapkan mampu mengubah tingkah laku peserta didik, (3) bahan ajar yang dikembangkan harus sesuai dengan kebutuhan dan karakteristik diri, (4) program belajar mengajar yang akan dilangsungkan, (5) di dalam bahan ajar telah mencakup tujuan kegiatan pembelajaran yang spesifik, (6) guna mendukung ketercapaian tujuan, bahan ajar harus memuat materi pembelajaran secara rinci, baik untuk kegiatan dan latihan, (7) terdapat evaluasi sebagai umpan balik dan alat untuk mengukur tingkat keberhasilan peserta didik.

\section{KESIMPULAN}

Dari beberapa pandangan di atas, dapat disimpulkan bahwa pengembangan bahan ajar merupakan segala bahan baik informasi, alat, maupun teks yang disusun secara sistematis, yang dapat menampilkan sosok utuh dan kompetensi yang akan dikuasainya. Pemahaman ini memberikan batasan kepada kita bahwa jika tidak dirancang secara sistematis, maka kita tidak bisa menyebutnya sebagai bahan ajar, walaupun bahan itu mengandung materi pelajaran.

Dengan adanya bahan ajar yang baik dapat memberikan kepada pendidik dan peserta didik dalam melakukan pembelajaran secara mandiri, apakah digunakan, kapan, di mana saja, maka bahan ajar tersebut dapat mengantarkan peserta didik belajar secara optimal. Apalagi bahan ajar tersebut dapat memberikan kontribusi yang positif kepada pendidik dalam melahirkan karya fenomenal, bahkan sebagai kenaikan pangkat. 


\section{DAFTAR PUSTAKA}

AECT. 1986. The Definition of Educational Technology. Washington, Published by Association for Eduactional Communication and Technology.

AECT. 1994. Media Pembelajaran. Depdiknas, Direktorat Jendelal Pendidikan Dasar dan Menengah, Direktorat Tenaga Kependidikan. Jakarta.

Amri. S. \& Ahmadi. L. K. 2010. Konstruksi Pengembangan Pembelajaran: Pengaruh Terhadap Mekanisme dan Praktik Kurikulum. Jakarta; Prestasi Pustaka Publisher.

Andi Prastowo. 2012. Panduan Kreatif Membuat Bahan Ajar Inovatif: Menicptakan Metode Pembelajaran Yang Menarik dan Menyenangkan. Cetakan keempat, Diva Press. Yogyakarta

Banathy. 1991. System Design of Education. New Jersey: Educational Technology Publications, Inc., Englewood Cliffs.

Degeng. 1989b. Teori Pembelajaran 2: Taksonomi Variabel Pengajaran Terapan. Depdikbud, Dirjen, Dikti, P2LPTK. Jakarta.

Degeng. 2008. Pedoman Penyusunan Bahan Ajar; Menuju Pribadi Unggul Lewat Perbaikan Kualitas Belajar Mengajar. Teknologi Pembelajaran Program Pascasarjana Universitas PGRI Adi Buana Surabaya.

Degeng. 1986. Teori Pembelajaran 1: Taksonomi Variabel. Depdikbud, Dirjen, Dikti, P2LPTK. Jakarta.

Diknas. 2004. Pedoman Umum Pemilihan dan Pemanfaatan Bahan Ajar. Ditjen Dikdasmenum. Jakarta

Diknas. 2004. Pedoman Umum Pengembangan Bahan Ajar. Ditjen Dikdasmenum. Jakarta

Gafar. 2002. Perancangan Pembelajaran Pendidikan Agama Islam. Tesis tidak dipublikasikan. Malang: PSSJ TEP UM.

Glaser. 1976. Components of a Psychology of Intruction: Toward a Science of Design. Review of Educational Research, 46: 1-24.

Januszewski. A. \& Molenda. M. 2008. Eduacational Technology: A Defintion with Commentary. Lawrence Erlbaum Associates is an imprint of Taylor \& Francis Group, an informa business.

Joni, dkk. 1984. Pengembangan Paket Belajar. Jakarta. Depdikbud, Dikjen, Dikti. Proyek Pembinaan Tenaga Kependidikan.

Hakim. 2001. Pengembangan Paket Pembelajaran Matakuliah Tinjauan Seni Rupa pada Jurusan Pendidikan Seni Rupa. Tesis tidak dipublikasikan, Malang, PSSJ TEP UM.

Mayer. 1982. Multi-Media Learning: Prinsip-Prinsip dan Aplikasi. Diterjemahkan oleh Teguh Wahyu Utomo. Pustaka Pelajar. Yogyakarta.

Miarso. 1987. Teknologi Komunikasi Pendidikan. Jakarta: CV, Rajawali

Panen. 1994. Penulisan Bahan Ajar. Pusat Antar Universitas Untuk Peningkatan dan Pengembangan Aktivitas Instruksional. Ditjen Dikti Diknas. Jakarta

Percipal dan Ellington. 1988. Teknologi Pendidikan. Terjemahan Sudjarwo S., Erlangga. Jakarta 
Artikel Teknologi Pendidikan 2012

Pribadi. B. A. 2009. Model Desain Sistem Pembelajaran. Jakarta: PT. Dian Rakyat

Robert Heinich dkk. 2005. Instructional Media. John Wiley \& Sons. New York

Seels \& Richey. 1994. Teknologi Pembelajaran: Definisi dan Kawasannya. Association for Educational Communications and Technology. Washington DC.

Syahid. 2003. Pengembangan Bahan Ajar Matakuliah Rancangan Pembelajaran dengan Menerapkan Model Elaborasi. Tesis tidak publikasikan. Malang: PSSJ TEP PPS UM.

Tarigan. 1989. Telaah Buku Teks Bahasa Indonesia. Bandung: Angkasa.

Widodo. C. S \& Jasmani. 2008. Panduan Menyusun Bahan Ajar Berbasis Kompetensi. Jakarta. Kompas Gramedia. PT. Elex Media Komputindo.

Uno. H. B., Lamatenggo. N., \& Koni. S, 2010. Desain Pembelajaran. Bandung: MQS Publishing. 